\title{
Financeirização imobiliária em dois momentos: da produção à ocupação via proptechs
}

\author{
End-to-end real estate financialization: \\ from developing to occupying through proptechs
}

Rafael Kalinoski [I] Mario Procopiuck [II]

\section{Resumo}

Na última década, proliferaram modelos de negócios imobiliários globais substitutivos da tradicional relação proprietário-locador intermediada por empresas locais. 0 objetivo deste artigo é analisar como a produção imobiliária é transformada pelo capital financeiro sob a perspectiva dos produtos imobiliários direcionados a investidores com locação comercializada em plataformas digitais. Metodologicamente, a investigação qualitativa segue a "trilha do dinheiro" que financia as startups do setor imobiliário, conhecidas como proptechs, de modo a identificar os agentes financeiros envolvidos. Os resultados apontam que a financeirização imobiliária, além de continuar a ocorrer na construção e na incorporação, avança para a ocupação via empresas permeadas pelo mercado de capitais. Conclui-se que os negócios imobiliários se complexificam em quatro ondas: financeirização, financeiro-desburocratização, financeiro-virtualização e, por fim, financeiro-virtualização compartilhada da ocupação imobiliária.

Palavras-chave: produção imobiliária; financeirização; virtualização; investimento imobiliário; proptechs.

\begin{abstract}
During the last decade, new global real estate business models have expanded and gradually replaced the traditional landlord-tenant relationship intermediated by local companies. This paper analyzes how real estate production is transformed by financial capital within the context of real estate products directed to investors and rented via digital platforms. Methodologically, the qualitative investigation follows the money that finances real estate startups, known as proptechs, to identify the financial agents involved. The results suggest that real estate financialization continues to occur in construction and development but has now advanced towards occupation intermediated by companies permeated by financial capital. The conclusion is that real estate businesses have become more complex in four waves: financialization, financialdebureaucratization, financial-virtualization, and shared financial-virtualization of real estate occupation.
\end{abstract}

Keywords: real estate development; financialization; virtualization; real estate investment; proptechs. 


\section{Introdução}

As tendências do capitalismo nos últimos 30 anos se apresentam por meio de três fenômenos: neoliberalismo, globalização e financeirização (Epstein, 2005). Enquanto os dois primeiros têm produção acadêmica que se apresenta de modo, poder-se-ia dizer, conclusivo (Arantes; Vainer e Maricato, 2002; Harvey, 2005 e 2008; Mattos, 2007), o terceiro levanta continuados questionamentos. À medida que as economias ocidentais se desindustrializaram nas últimas quatro décadas, ao transferir a produção para o oriente (Harvey, 2008), houve queda de arrecadação para o erário e diminuição de poder fiscal, especialmente na escala municipal (Soares, 2020).

Nesse momento, o produto imobiliário passa a ter papel crucial, pois não pode ser feito na Ásia e exportado para os países capitalistas centrais, pelo menos não em sua forma acabada. As cidades passaram a recorrer, então, a esse segmento para gerar empregos e impulsionar a economia local. Nesse processo, portanto, o produto imobiliário, face da esfera local e unidade básica da forma urbana, passa a ser permeado por interesses financeiros da economia política capitalista em escala global que precisa reinvestir o capital acumulado em outros setores da economia (Guironnet; Attuyer e Halbert, 2015; Aalbers e Haila, 2018; August, 2020; Charles, 2020; e López, 2020).

Os limites que a realização do capital encontrou na virada para o século XXI, que já conta com duas grandes crises financeiras em escala global (2008 e 2020), exigem a reinvenção dos mercados em busca da manutenção de trajetórias ascendentes de realização de lucros. Para evitar que a reprodução do capital desacelere, a gestão criativa do setor imobiliário produz novas ideologias para o habitar no espaço urbano, que se manifestam na publicidade do mercado imobiliário por meio de expressões como "moradia por assinatura", "moradia descomplicada", "moradia sem burocracia", "moradia compartilhada", dentre outras. Essas tentativas de conformação ideológica tendem a se circunscrever ao contexto de inflexão liberal da ordem urbana mundial. A propagação dessas ideologias vem naturalmente acompanhada pelo alinhamento da oferta de produtos, o que resulta na constante reinvenção dos padrões da reestruturação produtiva do setor.

O pós-crise de 2008 originou um modelo de negócios em que o tradicional pequeno proprietário-investidor de residências dedicado a gerar renda com aluguel foi gradualmente substituído por grandes investidores institucionais em escala global. O setor financeiro, que antes rentabilizava sobre o débito hipotecário e a securitização do débito, passou, então, a atuar também na receita de longo prazo, com 0 aluguel da habitação. Afinal, foram exatamente as táticas de alto risco de comercializar títulos hipotecários e de securitização que levaram ao colapso do sistema financeiro em 2008-2009 (Guironnet, Attuyer e Halbert, 2015; Charles, 2020; López, 2020).

Nesse contexto, emergem novas lógicas de produção imobiliária focada em investidores (institucionais ou pessoas físicas) que alugam seus imóveis para obter rentabilidade atrativa se comparada à renda fixa em contextos de juros baixos, como no caso atual do Brasil. Em paralelo, surgem plataformas digitais que facilitam a intermediação entre as intenções do proprietário-investidor e seu público-alvo. Adicionalmente, na nova lógica de exploração rentista do espaço urbano, 
os apartamentos compactos e os estúdios aparecem com mais frequência, pois o valor de venda é mais solvável que o de apartamentos maiores e, portanto, cabe na carteira de mais investidores (Valfré e Ribeiro, 2020). Esses novos produtos imobiliários estão direcionados às novas gerações de consumidores que, aos poucos, deixam de lado a ideologia da casa própria e veem a moradia como um serviço, em substituição ao modelo tradicional da moradia como o maior e mais importante ativo de um cidadão ou família. Os contratos desburocratizados que regulam essas novas relações comerciais tornam paulatinamente obsoleto o modelo tradicional de aluguel via imobiliárias locais ou vicinais pautado na relação mais pessoal entre locatário e locador.

No novo circuito de produção imobiliária, por meio de edifícios novos ou da revitalização de edifícios antigos nas áreas centrais, o capital financeiro atua nas duas pontas para obter rentabilidade via aluguel: na produção do imóvel, por meio da capitalização em bolsa de valores das maiores construtoras e incorporadoras; e na ocupação do imóvel, por meio da capitalização em bolsa das plataformas digitais de intermediação de aluguel e da retórica de ativo financeiro atribuída a imóveis comercializados via fundos de investimento imobiliário (FIls) ou financiamento coletivo (crowdfunding). Essa sequência de relações entre mercado financeiro e o ambiente construído é chamada neste artigo de financeirização em dois momentos: (I) produção e incorporação do imóvel e (II) ocupação intermediada por empresas de tecnologia que também são permeadas pelo capital financeiro global.
Em face de preocupações práticas e teóricas quanto aos impactos dessas novas estratégias do complexo imobiliário-financeiro (Santoro e Rolnik, 2017; López, 2020; e Melo, 2021), este artigo explora como se manifesta o segundo momento da financeirização, quando o empreendimento já financeirizado aparece na paisagem urbana e adentra a paisagem digital do capitalismo contemporâneo, que ocorre via plataformas potencializadoras da rentabilidade do proprietário-investidor. Sumarizado, o problema de pesquisa é a produção imobiliária voltada para investidores como fenômeno de financeirização do espaço urbano. Esse problema emerge da lacuna postulada por Fernandez e Aalbers (2016), ao afirmarem que, a despeito das amplas análises sobre financeirização como regime de acumulação, como incremento do valor do acionista e como financeirização da vida cotidiana, há questões que ainda demandam pesquisa e teorização, como a financeirização da habitação e a importância da habitação para a própria financeirização. Como a habitação é um fenômeno espacial, essa mesma lacuna é apontada por Cavalcante et al. ao afirmarem que "um atributo específico, frequentemente omitido das discussões sobre financeirização, é o espaço" (2018, p. 194).

A importância da habitação para a reinvenção das lógicas de atuação do mercado imobiliário será explorada, após breve revisão de literatura, por meio da análise de modelos de negócios de startups do mercado imobiliário, chamadas de proptechs, e da trilha percorrida pelo dinheiro que viabiliza a expansão dessas empresas no território brasileiro. 


\section{Financeirização e impactos na base material do mercado imobiliário}

Um ponto de partida importante para avançar na discussão de modo a entender a articulação entre o capitalismo e a estrutura do espaço urbano está no que se denomina "regime urbano" (Abramo, 1995), pois, segundo o autor, "os 'regimes urbanos' identificariam fases particulares da relação do capital e da estrutura urbana" (p. 511). 0 regime em vigor a cada momento tem impactos sobre o espaço que, por sua vez, se modifica à medida que as relações capitalistas também se transformam. O regime urbano pode ser, portanto, o pano de fundo dessa discussão sobre a produção imobiliária conduzida para valorizar o capital investido e gerar renda.

No contexto específico das discussões sobre o fenômeno financeirização, parece haver mais perguntas do que respostas sobre seus contornos teórico-conceituais. Não obstante, essas discussões são promissoras para explicar uma gama importante de acontecimentos das duas últimas décadas. Desde a bolha hipotecária de 2008, por exemplo, relega-se a segundo plano a ocupação da base material de moradia e foca-se em gerar valor financeiro. Em 2020, a "economia do distanciamento" reinventou o varejo, durante o isolamento social demandado pela pandemia, e esforçou-se em retóricas para gerar valor pela transformação do espaço-moradia em espaço-trabalho. A reversão das perdas financeiras do início da pandemia parece estar em processo na supervalorização de papéis de empresas capazes de manter suas atividades comerciais durante o confinamento por meio de redes logísticas bem estruturadas. Nesse contexto, como tentativa de contribuir para o preenchimento da lacuna apontada por Fernandez e Aalbers (2016), pretende-se tratar da financeirização do mercado imobiliário residencial e das novas formas que tem adquirido nos últimos anos.

Assim como o neoliberalismo, a financeirização não é monolítica, tampouco tem uma única face, pois varia entre as diferentes formações sociais (Theodore, Peck e Brenner, 2009). Uma definição específica de financeirização retrata um padrão de acumulação no qual a realização de lucros ocorre por meio de canais financeiros, em detrimento da produção de commodities e venda de produtos (Krippner, 2005). Contudo, o mercado imobiliário precisa que alguém o produza (a construtora) e que alguém conclua a venda (a incorporadora). E esses dois pontos de agência necessitam, evidentemente, de aportes financeiros, em que constantemente se reinventa a realização de lucros via mecanismos financeiros, como o financiamento bancário tradicional; a captação de recursos em bolsa de valores; e a emissão de debêntures, certificados de recebíveis imobiliários (CRIs), letras de crédito imobiliário (LCls) e cotas de Flls. Na esteira da reinvenção dos mecanismos financeiros, os modelos de negócios imobiliários também se reinventam sob o prisma das evoluções digitais, que permitem desburocratizar o aluguel e tornar esse aspecto da vida urbana algo que possa ser resolvido com um smartphone, como será explorado na seção de resultados.

A financeirização da construção e incorporação do produto imobiliário, chamada aqui de primeiro momento da financeirização, foi ampla e profundamente analisada em obras consolidadas na literatura brasileira, dentre as 
quais se destacam Fix (2011), Rufino (2012), Sanfelici (2013) e as produções dos núcleos do Observatório das Metrópoles que vigiam esse processo e suas peculiaridades por meio de estudos sobre regimes urbanos. No Brasil, esse primeiro momento da financeirização imobiliária residencial ocorre, pelo menos, desde a abertura de capital de construtoras e incorporadoras focadas na produção residencial em 2006 e 2007 (Miele, 2008), com crescimento acentuado da produção imobiliária após a crise de 2008, principalmente por conta de recursos do Programa Minha Casa Minha Vida e da disseminação de títulos lastreados no mercado imobiliário (Fix, 2009; Fix e Paulani, 2019; Sanfelici, 2013; Sanfelici e Halbert, 2016 e 2019).

Publicações e discussões da última década parecem convergir para a ideia de que está em curso um processo de transformar o modus operandi das instituições públicas para flexibilizar os atos normativos de planejamento urbano, o que favorece os negócios imobiliários e a captura de renda urbana por grandes grupos econômicos e seus investidores (Martins, 2020; Panizzi, 2020). O interesse da esfera municipal - representação última do Estado nas questões de gestão urbana (Silva e Procopiuck, 2019) - em permitir tal flexibilização estaria centrado no argumento de que essa seria uma das poucas alternativas para geração de empregos em massa em tempos de desindustrialização e crise econômica (Soares, 2020). Argumenta-se, ainda, que a cidade está cada vez mais caracterizada pela lógica das relações financeiras, segundo a qual "o que importa não é mais o modo como o espaço é ocupado, mas a liquidez com que o capital se realiza" (Panizzi, 2020, p. 19). 0 espaço construído passaria, portanto, a requerer retorno financeiro competitivo ao capital portador de juros.
Estado e mercado imobiliário apresentar-se-iam, sob tal lógica, cada vez mais imbricados na produção do espaço urbano. A realização de lucros do segundo torna-se crucial para a manutenção da atividade econômica do primeiro (Soares, 2020). Dessa forma, o Estado assume papel central no processo de criar e manter condições para que produtos imobiliários sejam "commodities financeiras". Primeiro, porque o Estado modela os marcos regulatórios e, segundo, porque pode influenciar as condições financeiras dos investimentos, incluindo a lucratividade (Halbert e Attuyer, 2016). A terra, base da produção imobiliária, passa a ser precificada como todo ativo financeiro; trata-se de um preço presente fundamentado na expectativa de um valor futuro. 0 mercado de terras torna-se, por essência, diretamente ligado às questões financeiras (Fix e Paulani, 2019), e dissipa-se, portanto, parte substancial dos seus valores de uso como estruturador das cidades.

Portanto, uma definição mais abrangente de financeirização pode ser mais adequada para esta discussão: trata-se "do papel crescente das intenções, dos mercados, dos atores e das instituições financeiras na operação das economias domésticas e internacionais" (Epstein, 2005, p. 3). A academia brasileira também apresenta uma definição ampla do fenômeno, que pode ser adequada a este trabalho: trata-se da influência das finanças sobre todas as esferas da sociedade, ultrapassando a esfera financeira per se e conformando as peculiari-dades do capitalismo contemporâneo (Sanfelici, 2013). Conforme será evidenciado pelos exemplos a seguir, modelos de negócios financeirizados estão em processo de substituir negócios imobiliários locais de intermediação entre proprietários-locadores e 
locatários-moradores para um modelo em que o proprietário é um investidor e o morador é um assinante de serviço digital. Nesses novos modelos, a empresa imobiliária tradicional é substituída por proptechs, plataformas digitais que têm sua própria estrutura financeirizada.

Ao analisar a abrangência do processo de financeirização, pesquisas destacam que ele "mobiliza diversas escalas, agentes (financeiros e não financeiros, públicos e privados), práticas (materiais e discursivas) e institucionalidades na transformação das economias, das corporações e da própria vida quotidiana" (Klink e Souza, 2017, p. 381). Nessa linha, a liberalização dos mercados de capitais e a criação de novas engenharias financeiras constituem ambiente propício para a circulação internacional de fluxos financeiros em escala com considerável ineditismo. Os projetos e as estratégias empresariais são marcados por retornos mais rápidos, obsolescência precoce de investimentos e ativos e ajustes espaciais intensos. Entender esse emaranhado de agentes envolvidos requer a compreensão da trilha do dinheiro.

A necessidade de encontrar lugar para a absorção do excedente de capital também leva à busca de novos mercados e à promoção de novos produtos e estilos de vida, aliados a mecanismos de crédito que viabilizem o consumo (Harvey, 2012). A urbanização passa, então, a contribuir ativamente para o desenvolvimento capitalista, o que configura um movimento de reestruturação da produção imobiliária. É preciso estar atento, portanto, para a premissa de que o mercado imobiliário não apenas soluciona necessidades existentes, como cria necessidades para as quais oferece soluções. É como se a criação de identidades e de ideologias sob lógicas de mercado modificasse a intimidade da vida privada à medida que o desenvolvimento de instituições financeiras está contido na crescente tendência de dominação de cada aspecto das relações sociais (Cavalcante et al., 2018).

Novos modelos de produção imobiliária também geram impactos na gestão do solo e nos fluxos da cidade. A gestão pode enfrentar desafios para permitir que novos empreendimentos sejam aprovados com mais unidades de tamanhos menores, bem como esperar um novo "morador-tipo" que priorize fluxos a pé, por transporte público ou por carro de aplicativo. Além disso, empreendimentos assim são mais "comercializáveis" quando localizados próximos aos melhores empregos e instituições educacionais, o que pode gerar pressão do mercado imobiliário pela "ressemantização das áreas centrais", por meio de novos empreendimentos ou de retrofit de edifícios antigos abandonados ou subutilizados (Lacerda e Bernardino, 2020). Movimentos do mercado imobiliário para lançar novos produtos em áreas centrais consideradas "degradadas" parecem ganhar fôlego com o processo de "destruição criativa" (Harvey, 2012), que catalisa novas frentes de expansão para o setor junto ao apelo ideológico de novos estilos de vida incorporados ao discurso do segundo momento da financeirização.

Esse segundo momento, no entanto, parece ainda não ter sido analisado em profundidade e refere-se à financeirização da ocupação imobiliária, que ocorre posterior e separadamente à financeirização da produção, principalmente por meio da economia de compartilhamento, submetida à lógica das tecnologias da informação e comunicação (TICS) e idealizada no contexto norte-americano a partir da crise de 2008. O aluguel sem burocracia, 
intermediado pelo celular ou computador, em detrimento da empresa imobiliária tradicional, parece ter chegado para ficar e causar rupturas no setor, principalmente entre os consumidores

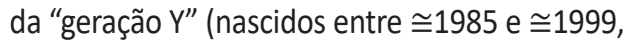
também chamados de millenials) e da "geração Z" (nascidos na virada do século), o que demanda ser estudado como componente das questões urbanas contemporâneas. Esse é um dos desafios propostos pelo presente artigo.

\section{Instrumentalização e discussões locais sobre financeirização imobiliária}

Instrumentalmente, os mecanismos que possibilitam o regime de financeirização do espaço urbano brasileiro começaram a ser institucionalizados nos anos 1990 e apresentam variações desde então. Dois marcos importantes foram a criação dos Flls, em 1993, e do Sistema Financeiro Imobiliário (SFI), em 1997. O SFI, com a garantia da alienação fiduciária, viabilizou a criação de novos instrumentos de captação de recursos para o mercado imobiliário, como os CRIs e as LCls (Santoro e Rolnik, 2017). Juntos, esses mecanismos representam o início da disseminação de valores mobiliários (papéis) negociados no mercado financeiro com lastro em valores imobiliários (imóveis).

Empenhados em desvendar esse primeiro momento da financeirização imobiliária, pesquisadores reuniram-se no I Seminário Internacional: Financeirização e Estudos Urbanos (USP, São Carlos, 2018) para compartilhar seus avanços. Esse seminário teve em sua sessão de encerramento um sentimento de satisfação por ter alinhado os diversos estudos sobre o tema, misturado com a agonia gerada pela quantidade de questões deixadas em aberto. Pesquisadores retornaram para as universidades do Brasil e do mundo com mais dúvidas do que convicções ao constatarem o quanto o tema ainda precisava ser elucidado e constantemente investigado. Essa vigilância epistemológica é essencial no contexto em que os regimes urbanos se reinventam sob o prisma da digitalização da economia e da crescente acessibilidade que o cidadão comum tem a diversos tipos de investimentos.

Alinhados a esse entendimento, Cavalcante et al. (2018) argumentam que a financeirização e o espaço têm uma relação sinérgica em que o contexto socioeconômico e o ambiente cultural determinam características específicas do processo que podem diferir do conhecido e amplamente discutido modelo anglo-saxão. Segundo os autores, o Brasil possui uma economia dual caracterizada por um centro dinâmico e uma grande periferia dependente. Essa dualidade foi identificada no estudo ao mapear agentes de financeirização e constatar a concentração dos agentes financeiros mais sofisticados nas regiões Sudeste, Sul e parte do Centro-Oeste. Em contraste, há espaços periféricos sem atuação de agentes financeiros ou com atuação de uma rede mais simples, como no Norte e em grande parte do Nordeste. Adicionalmente, o centro da financeirização mais sofisticada é mais conectado aos mercados globais e a outras regiões periféricas.

Essa lógica está associada a discussões globais que apontam que as estruturas financeiras tendem a ser distribuídas de forma desigual nas economias nacionais (Ioannou e Wójcik, 2021). Um padrão similar foi identificado, por exemplo, no contexto canadense, 
no qual a penetrabilidade dos real estate investment trusts (Reits, equivalentes aos FIls) no espaço urbano é inversamente proporcional à regulação dos aluguéis (August, 2020). O estudo aponta que, nas províncias canadenses onde não há regulação de aluguéis ou onde a regulação é fraca, o percentual de propriedades controladas por Reits é maior. Essas análises corroboram o papel central do Estado em possibilitar a exploração do espaço como commodity financeira à medida que ele coordena os marcos regulatórios (Halbert e Attuyer, 2016).

O estudo empírico apresentado a seguir contribuirá para compreender até que medida os mecanismos mais avançados do segundo momento da financeirização imobiliária também estão concentrados nas regiões brasileiras onde atuam os agentes financeiros mais sofisticados. Da mesma forma, a expansão de mecanismos como os Flls que será apresentada está em linha com os resultados de August (2020), ao levar-se em consideração que não há, no Brasil, políticas públicas consistentes para o controle do preço dos aluguéis, permitindo que os mecanismos financeiros se reinventem em busca da maior rentabilidade possível da propriedade urbana.

\section{Metodologia}

A metodologia é de caráter qualitativo, centrada em análise documental de empresas atuantes no segmento de intermediação de aluguéis por meio de plataformas digitais no Brasil (Quadro 1). O contexto macroeconômico é tomado como pano de fundo para interpretar as novas estratégias do complexo imobiliário- -financeiro em tempos de crise. Identificadas as empresas e alguns de seus empreendimentos que ilustram seu segmento de atuação, o método da trilha do dinheiro (follow de money) foi utilizado para entender quais são os agentes envolvidos nos dois momentos da financeirização, sempre com foco no segundo momento: a ocupação imobiliária. Entender a estrutura e o modus operandi de empresas envolvidas nesses novos produtos imobiliários é fundamental para entender os fluxos de capital que formam a estrutura da financeirização, pois ela se manifesta de diversas formas. Note-se que o foco da investigação está nos modelos de operações, e não nas empresas propriamente ditas, que apenas são utilizadas para fins de ilustração de características centrais dos modelos identificados e aplicados por cerca de mil empresas do ramo. ${ }^{1}$

É importante destacar que, a partir deste estudo inicial, a análise qualitativa de casos paradigmáticos da financeirização imobiliária poderá levar a generalizações do fenômeno. Além disso, analisar todas as plataformas concorrentes às tratadas nesse texto seria inviável neste primeiro momento exploratório, pois demandaria pesquisar o mercado imobiliário em todas as capitais e cidades médias do País. Todavia, a análise pormenorizada de alguns casos permite avançar na compreensão de um fenômeno amplo que ainda tem relativamente pouca pesquisa científica. Além do mais, como a pesquisa explora empresas cuja atuação transita entre o setor de tecnologia e o setor imobiliário, trata-se de modelos de negócios que têm se transformado rapidamente, à velocidade do avanço da virtualização das relações sociais.

$\mathrm{Na}$ abordagem inicial da pesquisa, não havia um pré-entendimento a respeito da estrutura de capital e das estratégias de atuação 
Quadro 1 - Empresas pesquisadas

\begin{tabular}{|c|c|c|c|c|}
\hline \multirow{2}{*}{$\begin{array}{l}\text { Empresas/ } \\
\text { Proptechs }\end{array}$} & \multirow{2}{*}{ Área geográfica de atuação } & \multirow{2}{*}{ Segmento de atuação } & \multicolumn{2}{|c|}{ Ambiente de atuação } \\
\hline & & & Website & App \\
\hline Airbnb & Escala global & Aluguel de curtíssimo prazo (mín. 1 dia) & Sim & Sim \\
\hline Housi & $\begin{array}{l}\text { São Paulo, com planos de expansão } \\
\text { para outras capitais, cidades } \\
\text { médias do interior e América Latina }\end{array}$ & $\begin{array}{l}\text { Aluguel para médio e longo prazo } \\
\text { (mínimo } 1 \text { mês) }\end{array}$ & Sim & Sim \\
\hline $\begin{array}{l}\text { Quinto } \\
\text { Andar }\end{array}$ & $\begin{array}{l}\text { Capitais do AM, ES, DF, GO, BA, PA } \\
\text { e PE; e capitais e cidades médias de } \\
\text { MG, RS, PR, SC, SP e RJ }\end{array}$ & $\begin{array}{l}\text { Aluguel para médio e longo prazo } \\
\text { sem mínimo, porém a maioria dos } \\
\text { imóveis demanda que o locatário insira } \\
\text { mobiliário, o que denora foco em prazos } \\
\text { maiores) }\end{array}$ & Sim & Sim \\
\hline Shortstay & Curitiba & $\begin{array}{l}\text { Aluguel para curto e médio prazo } \\
\text { (mínimo } 1 \text { mês) }\end{array}$ & Sim & Não \\
\hline Yuca & São Paulo & $\begin{array}{l}\text { Aluguel compartilhado sem prazo } \\
\text { determinado, em imóveis reformados e } \\
\text { decorados pela própria Yuca }\end{array}$ & Sim & Sim \\
\hline Roomgo & Escala global & $\begin{array}{l}\text { Aluguel compartilhado sem prazo } \\
\text { determinado, compartilhado com } \\
\text { o proprietário do imóvel ou outros } \\
\text { usuários }\end{array}$ & Sim & Não \\
\hline
\end{tabular}

Fonte: elaboração dos autores, em 2021. Dados de julho de 2021.

por detrás de cada empresa analisada. Havia, no entanto, a percepção de que elas ofereciam serviços semelhantes: o aluguel descomplicado, digital, sem fiador, intermediado do início ao fim por canais digitais. Havia também a percepção de que os imóveis comercializados nessas plataformas tinham seu marketing em catálogos de lançamento, websites e redes sociais voltado a um público jovem e disposto a aderir a uma rotina em apartamentos compactos, porém bem localizados no espaço urbano. Por vezes, procura-se agregar valor aos imóveis pela associação com atributos funcionais das cidades, destacando-se a proximidade ao transporte público e a localização em bairros onde se concentram os empregos de melhor remuneração e as melhores instituições de ensino.

Os dados compilados neste artigo foram extraídos do website de cada empresa, de fontes jornalísticas que exploram a dinâmica de capitais e investimentos em startups (como Brazil Journal, Exame, InfoMoney, Terra, The New York Times e Veja) e, no caso do Airbnb, de uma plataforma (AirDNA) que extrai e centraliza os quantitativos de anúncios ativos e as características dos anúncios por cidade. Ao longo das quatro subseções da apresentação e análise dos resultados, os dados sistematizados foram interpretados à luz do estado-da-arte teórico inicialmente apresentado e discutido. 


\section{Apresentação e análise dos resultados}

Os resultados e as análises desenvolvidas vinculam-se às categorias financeirização, financeiro-desburocratização, financeiro-virtualização e financeiro-virtualização compartilhada da ocupação imobiliária. Essas quatro categorias identificadas parecem emergir sistemática e estruturalmente na realidade empírica atual do mercado imobiliário.

\section{A financeirização da ocupação imobiliária}

O fenômeno da produção imobiliária voltada a investidores é passível de ser entendido sob duas lentes. A primeira é o que a literatura denominou complexo imobiliário-financeiro: a superposição do mercado financeiro ao mercado imobiliário com o objetivo de valorizar o capital financeiro mediante produção e comercialização de imóveis como suportes materiais das atividades sociais e econômicas no espaço urbano (Santoro e Rolnik, 2017; López, 2020). Essa nova estrutura forjou processos de reestruturação territorial nos quais a produção do espaço urbano tem sido majoritariamente coordenada pelo setor privado.

A segunda lente para compreender o fenômeno, restringindo agora a discussão ao contexto brasileiro, é a sequência de baixas na taxa básica de juros (Selic) (Figura 1). As baixas na taxa Selic possibilitaram que o mercado imobiliário tomasse mais empréstimos para investir no setor, pois, na outra ponta, o comprador do imóvel também tem ofertas mais atrativas de financiamento a juros mais

Figura 1 - Trajetória da taxa Selic comparada ao número de investidores em Flls na bolsa

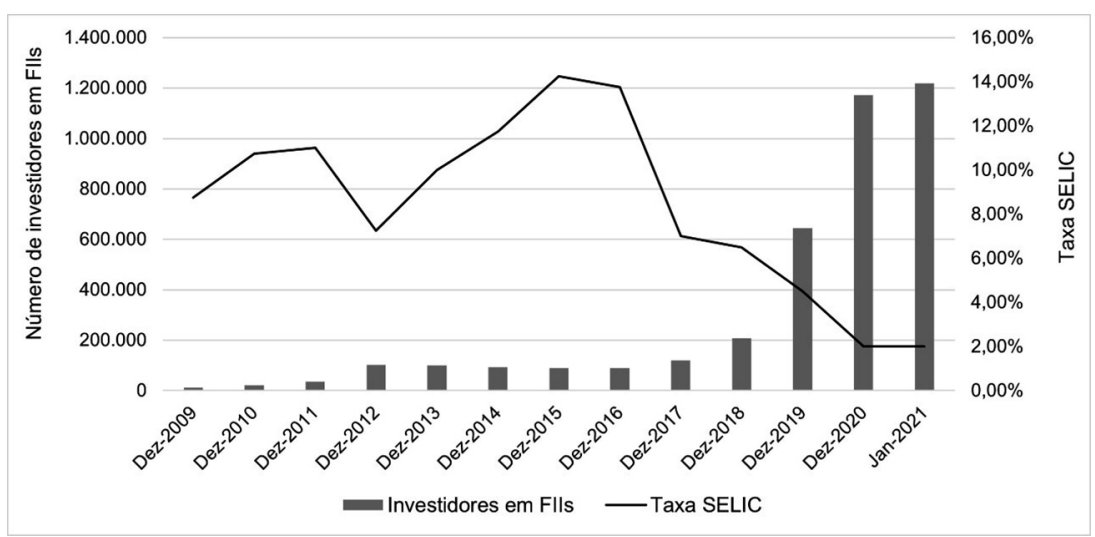

Fonte dos dados: Banco Central do Brasil e B3. Elaboração: os autores, em 2021. 
baixos. Paralelamente à perda de atratividade de investimentos cujo benchmarking é a taxa Selic, dois movimentos intensificaram-se a partir da ação de investidores em busca de maiores rendimentos: investir em imóveis para aluguel e investir em renda variável (ações de todos os setores da economia e/ou Flls, ambas negociadas em bolsa). É importante notar que, embora o Banco Central tenha iniciado, em março de 2021, um novo ciclo de altas na Selic, os juros reais continuam negativos (7/2021), já que a taxa de inflação é maior que a taxa básica de juros do País.

Apesar de a prática de comprar imóveis para obter renda com o aluguel permear toda a história do Brasil urbano, trata-se aqui de um novo contorno dado pelas possibilidades trazidas ao mercado imobiliário pelas proptechs. Se antes a relação entre locador e locatário era uma relação entre pessoas físicas, intermediada ou não por uma empresa imobiliária, agora ela passa a ser intermediada por plataformas digitais ligadas ao mercado aberto de capitais (bolsas de valores) ou à circulação do capital de risco. Dessa forma, o investidor pessoa física insere-se no complexo imobiliário-financeiro como proprietário-investidor de imóveis ou cotas de imóveis. Esse complexo que, no primeiro momento da financeirização (construção e incorporação), era uma relação de três lados, passa a ser uma relação quadrilátera (Figura 2).

Se, no primeiro momento da financeirização, o marco foi a onda de capitalização de construtoras e incorporadoras na bolsa de valores; no segundo momento surgiram dois eventos a serem analisados. Para os investidores tradicionais, que preferem bens tangíveis, quando o proprietário está em posse da chave e da escritura do imóvel, o mercado imobiliário passa a ofertar imóveis cujos anúncios não são focados na experiência de habitar, mas, sim, na rentabilidade que aquele imóvel pode oferecer a longo do tempo (Valfré e Ribeiro, 2020).

Figura 2 - Complexo imobiliário-financeiro na financeirização em dois momentos

PRIMEIRO MOMENTO

Construção e Incorporação

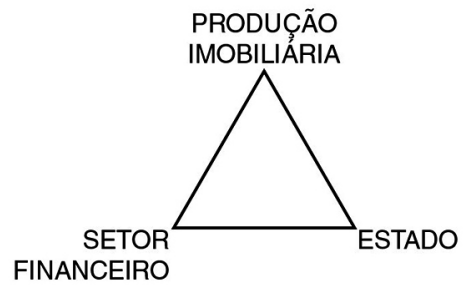

SEGUNDO MOMENTO

Ocupação

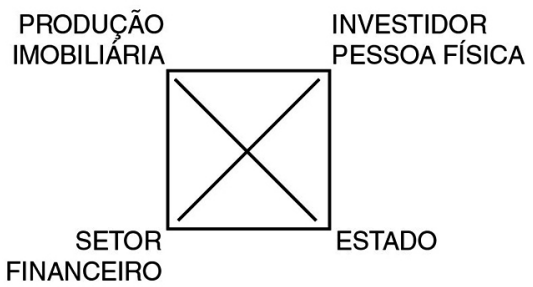

Fonte: elaborado pelos autores, em 2021. 
Dentre as construtoras e incorporadoras brasileiras, esse apelo de marketing se faz presente, por exemplo, de forma mais evidente nos empreendimentos lançados pela Vitacon (Figura 3) e nos imóveis operados por sua empresa derivada, a Housi. Quando localizados fora de São Paulo, área de atuação de Vitacon, os imóveis operados pela Housi são construídos e incorporados por empresas locais que formam uma rede de agentes imobiliários em processo de implantar a lógica da "moradia por assinatura" por todo o Brasil.

Para os investidores confortáveis com investimentos em bens intangíveis, chamados de papéis, o caminho para a captação de recursos que permitem a expansão do setor ocorre pela emissão de ações, cotas de Flls ou financiamentos coletivos de imóveis circunscritos a determinadas plataformas de locação, conforme será explorado em momento seguinte do presente artigo. É como se os investidores intangíveis financiassem o investimento tangível e o mercado imobiliário estivesse apenas intermediando a circulação do dinheiro por meio de estratégias que garantem rentabilidade a ambos, inserindo-se por completo na lógica do mercado financeiro.

Atualmente (3/7/2021), a bolsa de valores brasileira, B3, possui 360 Flls listados. Apesar da tradição em fundos de galpões logísticos, lajes comerciais, hospitais, escolas e agências bancárias, dentre outros, os fundos imobiliários residenciais são uma novidade que ganhou espaço em 2020, no mesmo contexto

Figura 3 - Sequência de anúncios da Vitacon

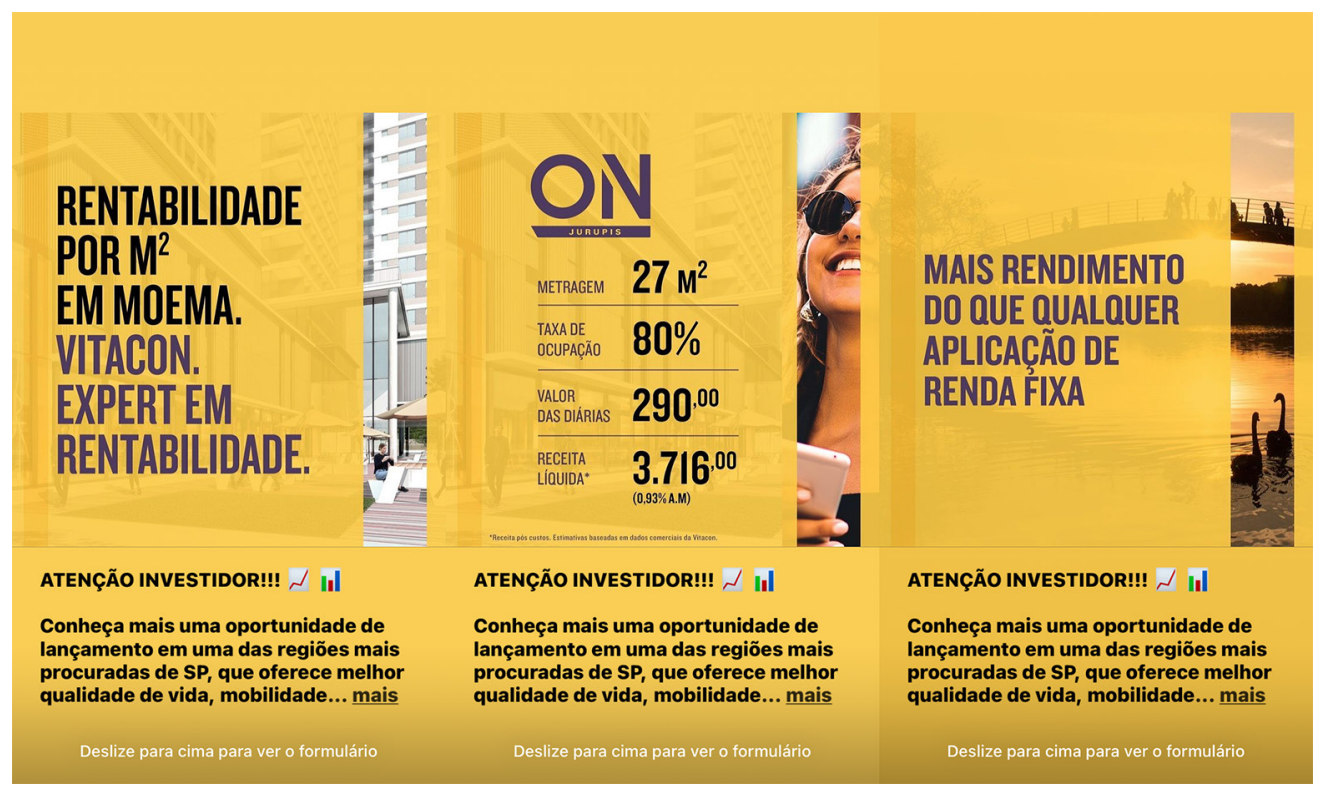

Fonte: anúncios patrocinados no Instagram @vitaconoficial em janeiro de 2021. 
de forte apelo pelo investimento em imóveis em detrimento do investimento em renda fixa no ambiente de juros baixos descrito anteriormente. Segundo artigo do InfoMoney, braço jornalístico do Grupo XP, há 19 fundos imobiliários com algum foco no mercado residencial (aluguéis, incorporação, compra e/ou venda), dentre os quais o fundo da Housi (D'Ávila, 2020). Apesar de apenas mencionado neste artigo, o caso da expansão dos Flls voltados ao mercado residencial demanda um esforço de pesquisa exclusivo para ser escrutinado e compreendido em momento oportuno.

Algumas empresas se destacam na manifestação da desburocratização da moradia alugada no Brasil com estratégias de mercado que permitem firmar contratos totalmente digitais, em sua maioria flexíveis quanto ao tempo de duração e com pagamentos via cartão de crédito, que podem atrelar outros benefícios ao locatário, como o acúmulo de pontos ou cashback. Na sequência, apresenta-se um panorama das principais estratégias que compõem esse processo de reestruturação do mercado de aluguéis, delineando o segundo momento da financeirização do mercado imobiliário.

\section{A financeiro-desburocratização da ocupação imobiliária}

No mercado brasileiro, desde 2012, a companhia do Vale do Silício Airbnb é a mais capilar dentre as discutidas neste artigo. Surgiu no contexto norte-americano da crise de 2008, quando seus fundadores decidiram alugar um colchão de ar no modelo bed and break-fast (daí o nome Air + bnb). A partir da experiência, emergiu um modelo internacional de hospedagem descomplicada, financiado inicialmente por capital de risco que, por vezes, foi interpretado como concorrência desleal ao setor hoteleiro.

Em 2020, a empresa realizou a maior oferta inicial de ações (IPO) na bolsa de Nasdaq (Griffith, 2020). A alta demanda pelos papéis levou seu valor de mercado a 100 bilhões de dólares. Vendidos inicialmente a 68 dólares, fecharam o primeiro dia na bolsa a 144 dólares (Sorkin et al., 2020), o que representou alta de $112 \%$ naquele primeiro dia no mercado de ações. É importante notar que o contexto de forte valorização dos papéis foi a injeção de trilhões de dólares na economia norte-americana por parte do Federal Reserve. Isso levantou especulações sobre a possibilidade de formação de uma bolha no mercado financeiro, já que os papéis, especialmente das empresas de tecnologia, valorizaram-se vertiginosamente em meio à maior crise da década. Com novos estímulos financeiros federais no início de 2021 e a reação positiva do mercado, os papéis chegaram a 216 dólares no seu pico, em 11/2/2021.

No Brasil, os papéis da empresa podem ser adquiridos desde 1으리 2021 por meio de Brazilian Depositary Receipts (BDRs) negociados na B3. ${ }^{2}$ Para compreender a dimensão da atuação do Airbnb no Brasil, a discussão será restringida às cidades-polo das 15 "redes de primeiro nível", caracterizadas como metrópoles pelo estudo da Região de Influência das Cidades de 2018 (IBGE, 2020). Na Tabela 1, apresenta-se o perfil dos anúncios da plataforma no Brasil e o custo médio de aluguel desses imóveis.

Os dados permitem concluir que imóveis compactos (estúdios ou 1 dormitório) são os mais comercializados na plataforma e que 0 
Tabela 1 - Anúncios do Airbnb ativos nas metrópoles brasileiras

\begin{tabular}{|c|c|c|c|c|c|c|c|c|}
\hline \multirow[b]{2}{*}{$\begin{array}{l}\text { Cidade-polo } \\
\text { da metrópole }\end{array}$} & \multirow{2}{*}{$\begin{array}{c}\text { Imóveis } \\
\text { ativos na } \\
\text { plataforma }\end{array}$} & \multirow{2}{*}{\begin{tabular}{|c|} 
Imóveis \\
Inteiros, não- \\
-compartilhados \\
(em \%)
\end{tabular}} & \multicolumn{4}{|c|}{ Principais imóveis-tipo (em \%) } & \multicolumn{2}{|c|}{ Média (em R\$̣) } \\
\hline & & & Estúdios & $\begin{array}{c}1 \\
\text { dorm. }\end{array}$ & $\begin{array}{c}2 \\
\text { dorms. }\end{array}$ & $\begin{array}{c}3 \\
\text { dorms+ }\end{array}$ & $\begin{array}{l}\text { Diária } \\
\text { (a) }\end{array}$ & $\begin{array}{l}\text { Mensal } \\
(=a * 30)\end{array}$ \\
\hline São Paulo & 12.159 & 67 & 17 & 59 & 18 & 6 & 196 & 5.880 \\
\hline Brasília & 1.095 & 76 & 18 & 71 & 6 & 5 & 145 & 4.350 \\
\hline Rio de Janeiro & 17.788 & 75 & 9 & 41 & 30 & 20 & 342 & 10.260 \\
\hline Belém & 451 & 60 & 7 & 45 & 29 & 19 & 139 & 4.170 \\
\hline Belo Horizonte & 1.581 & 54 & 5 & 39 & 29 & 27 & 159 & 4.770 \\
\hline Campinas & 834 & 57 & 10 & 50 & 17 & 23 & 154 & 4.620 \\
\hline Curitiba & 2.437 & 75 & 17 & 55 & 17 & 11 & 124 & 3.720 \\
\hline Florianópolis & 15.697 & 86 & 4 & 32 & 39 & 25 & 347 & 10.410 \\
\hline Fortaleza & 2.399 & 75 & 4 & 33 & 46 & 17 & 200 & 6.000 \\
\hline Goiânia & 1.102 & 78 & 11 & 57 & 22 & 10 & 141 & 4.230 \\
\hline Manaus & 530 & 60 & 6 & 51 & 29 & 14 & 123 & 3.690 \\
\hline Porto Alegre & 1.643 & 72 & 13 & 56 & 23 & 8 & 132 & 3.960 \\
\hline Recife & 1.692 & 72 & 8 & 50 & 27 & 15 & 165 & 4.950 \\
\hline Salvador & 3.785 & 72 & 7 & 45 & 25 & 23 & 214 & 6.420 \\
\hline Grande Vitória* & 3.570 & 85 & 2 & 21 & 39 & 38 & 250 & 7.500 \\
\hline
\end{tabular}

Fonte dos Dados: Plataforma AIRDNA (airdna.co). Data da coleta: 25/2/2021. Organização: os autores.

Observação: Os dados referem-se aos anúncios circunscritos ao limite municipal da cidade-polo de cada metrópole, e não à região metropolitana como um todo.

* No caso de Vitória, a plataforma não permitiu separar os dados do município de Vitória, fornecendo apenas os dados da região denominada Grande Vitória.

custo médio da diária multiplicado por 30 dias indica rentabilidade bruta mensal acima de valores do mercado convencional de aluguéis. Além disso, em cada uma das metrópoles, os anúncios tendem a ser concentrados em regiões específicas da cidade. No caso das cidades litorâneas, por exemplo, essa concentração é ao longo das praias. No caso de Curitiba, por exemplo, a concentração está nos eixos estruturais da cidade. A análise dos anúncios de Airbnb nas metrópoles brasileiras ainda possui diversas frentes para a expansão da pesquisa, contudo, o objetivo, neste momento, é apontar a importância dessa empresa global nos estudos sobre a dinâmica imobiliária local.

Percebe-se que a financeiro-desburocratização da ocupação imobiliária viabilizada pelo Airbnb tem ampla aderência em território brasileiro, somando mais de 66 mil imóveis listados apenas nos municípios-polo de metrópoles. Esse novo paradigma descomplicado da locação de curto prazo parece ter 
induzido o surgimento de outras proptechs que reproduzem o modelo desburocratizado também para o aluguel de médio e longo prazo, adotando o espaço virtual como locus das transações financeiras da ocupação imobiliária.

\section{A financeiro-virtualização \\ da ocupação imobiliária}

A construtora Vitacon surgiu em 2009 voltada para o segmento de imóveis compactos em São Paulo. Em 2018, foi fundada uma empresa derivada, a Housi, que oferece um serviço inédito no Brasil, a "moradia por assinatura". Trata-se de um modelo de aluguel que se assemelha ao setor hoteleiro e ao Airbnb, mas que é pensado para prazos maiores e para facilitar a alternância entre diferentes imóveis da rede que planeja a expansão em metrópoles e cidades médias brasileiras e, futuramente, pela América Latina.

Imóveis compactos são mais solváveis, pois seu valor de venda "cabe no bolso" de uma parcela maior da população, facilitando a liquidez das transações (Valfré e Ribeiro, 2020). Em sua comercialização, é adotado um discurso de marketing focado na rentabilidade, por vezes comparada com a renda fixa e com a Selic baixa (4.25\% a.a. em 3/7/2021). Além disso, reforça-se a narrativa de um novo estilo de vida descompromissado, independente de financiamentos imobiliários de longo prazo. Essa estratégia vem sendo adotada de maneira incisiva pela Vitacon, que utiliza bastante as redes sociais para anunciar seus produtos e sua abordagem de mercado. Ao podcast SP Sonha da Veja, o CEO da Vitacon afirma que "Moradia será cada vez mais um serviço. Você muda de casa de acordo com a mudança no trabalho, quando tem filhos, quando eles se casam. Vai de uma unidade maior a uma menor, de forma dinâmica. Se a vida muda tantas vezes, não faz sentido imobilizar seu dinheiro em um financiamento de 30 anos". $^{3}$

A moradia por assinatura insere-se no mercado de capitais por, ao menos, duas frentes. Em 2019, a Redpoint, gestora de capital de risco, aportou 50 milhões de reais na Housi. Em 2020, a Housi lançou o IPO do FII HOSI11, ${ }^{4}$ gerido pela Easynvest Gestão de Recursos Ltda. e administrado pela Vortx Distribuidora de Títulos e Valores Mobiliários Ltda. Com patrimônio líquido de cerca de R\$54 milhões e 573.450 cotas (dados de 29/1/2021), o valor patrimonial por cota era de R\$93. Naquela mesma data, as cotas fecharam em $\mathrm{R} \$ 85,32$ na bolsa, com o P/ VP de 0,92, indicando atratividade de compra, pois o preço de negociação da cota $(\mathrm{P})$ estava abaixo de seu valor patrimonial (VP). ${ }^{5}$

É importante notar que, apesar da ampla atuação da Vitacon em São Paulo e dos planos de expansão da Housi, apenas dois imóveis fazem parte do fundo. Esses imóveis são o Housi Jaú e o Housi Urussuí, ambos em construção em São Paulo e com início de operação na plataforma previsto para 2023. O primeiro promete aluguel médio de R\$3.100/mês em 126 unidades, que variam de 19 a $50 \mathrm{~m}^{2}$. 0 segundo promete aluguel médio de $R \$ 4.150 / \mathrm{mês}$ em 122 unidades, que variam de 18 a $40 \mathrm{~m}^{2}$. Do total da carteira do fundo, $61 \%$ do montante equivale ao Housi Urussuí, 27\% ao Housi Jaú e $12 \%$ é valor em caixa.

Apesar de os empreendimentos terem lançamento programado para 2023, o fundo já paga dividendos a seus cotistas. 0 dividend yield ${ }^{6}$ oscilou de $0,57 \%$ do valor da cota nos meses de novembro e dezembro de 2020 a $0,76 \%$ do valor da cota em outubro de 2020 . Nesse mesmo período, com a Selic a $2 \%$ a.a., 
fica evidente a atratividade do investimento nesse Fll para investidores dispostos a assumir riscos de mercado em busca de melhor rentabilidade. Entre 31/7/2020 e 29/1/2021, as cotas do fundo valorizaram-se $6,65 \%$, enquanto o benchmarking de Flls, o índice Ifix, teve valorização de 5,34\%, segundo relatório do fundo. Isso significa que o capital investido se valoriza a partir da flutuação de oferta e procura das cotas em bolsa e oferece rendimentos mensais superiores a três vezes a remuneração da poupança, por exemplo, que hoje paga apenas $70 \%$ da taxa Selic.

Além do fundo HOSI11, a empresa tem uma estratégia ampla de atuação por meio da comercialização de imóveis compactos inteiros para investidores que prefiram o bem tangível, mas que é completamente operado pela plataforma, reduzindo o ônus do proprietário com a manutenção do imóvel e o risco de inadimplência no contrato de aluguel. Pelo modelo de franquias, a Housi anunciou expansão para mais 15 cidades em 2020 e previu outras 40 para 2021. Ao fechar negócios com franqueados, que são incorporadoras regionais de diversas partes do Brasil, a Housi oferece sua bandeira de serviços e é remunerada com uma parcela desconhecida do valor geral de venda (VGV) do empreendimento. "A Housi está funcionando como o software, o sistema operacional dos prédios das incorporadoras parceiras", afirma o fundador (Sambrana, 2021). Por meio da função "plugar um imóvel", a Housi assemelha-se ao Airbnb, permitindo que imóveis individuais ou empreendimentos inteiros produzidos por outras construtoras sejam incluídos na plataforma. Desse modo, a Housi expande-se pelo Brasil de forma independente da Vitacon, que atua apenas em São Paulo.
No que diz respeito à expansão do serviço pelo Brasil, dois empreendimentos em construção destacam-se por estarem relacionados à discussão sobre "ressemantização das áreas centrais" por meio de novos empreendimentos ou de retrofit de edifícios antigos abandonados ou subutilizados (Lacerda e Bernardino, 2020). Trata-se do Viva Curitiba Studios, no centro de Curitiba, e do Infinita Town.co, em Porto Alegre. Ambos os empreendimentos estão sendo executados por incorporadoras locais e serão operados como franquia Housi. Nos dois casos, trata-se do retrofit de hotéis abandonados na área central dessas cidades, que estão passando por reforma para serem transformados em 144 unidades de 20 a 46 $\mathrm{m}^{2}$, no caso de Curitiba, e 180 unidades de 20 a $30 \mathrm{~m}^{2}$, no caso de Porto Alegre. São unidades completamente decoradas, equipadas para viver, e com foco em compradores-investidores (Figura 4).

De acordo com o discurso adotado no marketing de lançamento desses edifícios, percebe-se que os empreendimentos são direcionados para moradores inclinados a um estilo de vida descomplicado, que vai na contramão do tradicional sonho da casa própria e do carro próprio. Trata-se de um contexto de digitalização de diversas esferas da vida urbana, segundo o qual serviços de moradia e transporte estão a um toque da tela do ceIular. Os empreendimentos que operam no modelo Housi possuem diversos cômodos tradicionalmente individuais do apartamento (área de serviço e escritório, por exemplo), convertidos em espaços coletivos (lavanderia coletiva e coworking), além da possibilidade de contratar serviços sob demanda, como faxina, pelo aplicativo da empresa. 
Figura 4 - Material publicitário do Viva Curitiba e do Town.co.

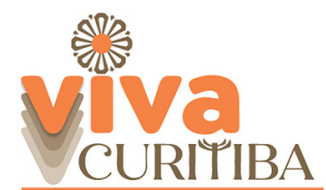

o jeito novo de investir

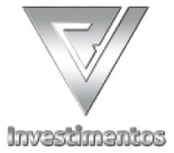
POWERED
BY HOUSI

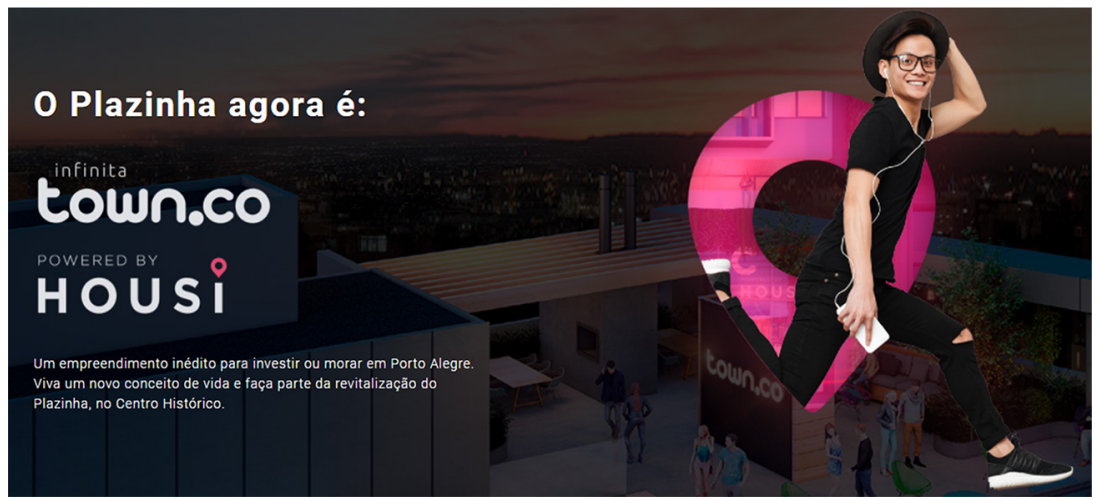

Fonte: catálogo de lançamento distribuído digitalmente (2020) e infinitatownco.com.br.

No caso da Housi, a financeiro-virtualização da ocupação imobiliária acontece, então, de duas formas: (I) por meio da emissão de cotas do FII e (II) por meio da venda de unidades para investidores que podem "plugar" o apartamento na plataforma. Trata-se, respectivamente, de um modelo de (I) investimento intangível via venda de papéis em bolsa; e de um modelo de (II) investimento tangível, via venda de unidades escrituradas que serão operadas no sistema da proptech, retirando do proprietário o ônus de encontrar seu locatário, intermediar o contrato e assumir o risco desse contrato. Operando dessas duas formas, esse segmento do mercado imobiliário absorve tanto os investidores inclinados a compra de papéis no mercado financeiro quanto os investidores tradicionais, donos de imóveis inteiros. Das duas formas, o espaço virtual possibilitado pelas TICs é central no processo.

Uma abordagem semelhante na ocupação do produto imobiliário é oferecida pela Quinto Andar, uma "imobiliária digital" (Quadro 2) que tem potencial de tornar obsoleto o modelo tradicional de aluguel via empresas imobiliárias locais, ao possibilitar o aluguel sem fiador, mediante análise de crédito, de imóveis espalhados pelos Brasil e centralizados em sua plataforma. Caso o interessado no aluguel não seja aprovado na análise de crédito, pode contratar seguro-fiança. Para o proprietário do imóvel, o risco de inadimplência do aluguel é eliminado. Toda a negociação é feita on-line, desde $o$ anúncio até a assinatura do contrato. 
Quadro 2 - Financeirização em dois momentos de empreendimentos anunciados pela Quinto Andar

\begin{tabular}{|c|c|c|c|}
\hline $\begin{array}{c}\text { Construção e incorporação } \\
\text { 10 momento da financeirização }\end{array}$ & Empreendimento & \multicolumn{2}{|c|}{ Ocupação } \\
\hline 2o momento da financeirização
\end{tabular}

Fonte das informações: Veja (2019) e websites dos investidores. Organização: os autores (2021).

Criada em 2013, a empresa atingiu o status de "unicórnio"7 do mercado após um aporte de 250 milhões de dólares feito, em 2019, pelo SoftBank, conglomerado japonês focado em investimentos nos setores de tecnologia, energia e serviços financeiros. Já eram investidores da Quinto Andar, a General Atlantic, empresa estadunidense focada em investimentos no crescimento de companhias já desenvolvidas ou growth equity; e a Kaszek, grupo argentino no segmento de investimentos de risco ou venture capital (Veja, 2019). Essa trilha do dinheiro permite perceber como o mercado tradicional de aluguel, antes intermediando proprietários e moradores em escala local, por vezes até mesmo vicinal, passa a ser substituído por um modelo de atuação nacional permeado por investimentos de diversos países, denotando que a financeiro-virtualização da ocupação imobiliária pode efetivar todos os tipos de contratos, do curtíssimo ao longo prazo. Ao contrário da Housi, o modelo da Quinto Andar possui imóveis com todos os tamanhos, de estúdios a diversos dormitórios, com público-alvo amplo e foco em uma gama maior de necessidades.

Ainda nesse grupo de empresas, agora restrita ao mercado curitibano, a Shortstay é uma plataforma que intermedeia a locação de apartamentos e flats mobiliados com contratos flexíveis de, pelo menos, um mês. A proptech, assim como Airbnb, aceita pagamento do aluguel com cartão de crédito, o que representa mais uma via de inserção do setor financeiro por meio do lucro da transação financeira por intermédio de operadora de cartão. A empresa declara-se "especialista na rentabilização de apartamentos compactos, centrais e mobiliados em Curitiba com portfólio de mais de 500 imóveis e milhares de contratos de locação já firmados" e destaca sua facilidade de negociação ante o modelo de aluguel por imobiliárias tradicionais, notoriamente demorado e burocrático.

As facilidades oferecidas pela Shortstay, como serviços de lavanderia e o atendimento bilíngue, denotam o direcionamento para um público de maior poder aquisitivo que trata a moradia como um serviço transitório que permite mobilidade no mundo globalizado. Um dos empreendimentos mais recentes anunciado na plataforma, de 2018, é o All you need, localizado em uma região do centro de Curitiba onde, argumenta-se, está em curso um processo de gentrificação (Weigert, 2020). Ao seguir a trilha do dinheiro envolvido nesse empreendimento, percebe que o circuito do capital começa e termina no exterior, pois o principal 
sócio da construtora é o fundo norte americano Equity International e, além da Shortstay, o imóvel também é anunciado em plataformas como Airbnb e Booking (Quadro 3).

No modelo de empreendimentos pensados de modo que a oferta de locação ocorra simultaneamente em diversas plataformas, essa intenção já está manifesta no material publicitário de lançamento do imóvel, como é possível verificar no catálogo de lançamento do All You Need e nos anúncios patrocinados no Instagram do empreendimento Vibe da Incorporadora Altma, em fase de construção em Curitiba (Figura 5). Embora o principal agente que esteja promovendo o Vibe seja a Housi, a incorporadora deixa claro que o sistema de locação será híbrido, buscando alcançar os usuários de plataformas concorrentes.

Quadro 3 - Trilha do dinheiro de empreendimento financeirizado em dois momentos

\begin{tabular}{|c|c|c|c|}
\hline \multicolumn{2}{|c|}{$\begin{array}{l}\text { Construção e incorporação } \\
10 \text { momento da financeirização }\end{array}$} & Empreendimento & $\begin{array}{c}\text { Ocupação } \\
\text { 2ㅇ momento da financeirização }\end{array}$ \\
\hline \multirow{2}{*}{\multicolumn{2}{|c|}{$\begin{array}{c}\text { GT Building Incorporadora, } \\
\text { Curitiba }\end{array}$}} & \multirow{3}{*}{$\begin{array}{l}\text { All You Need } \\
\text { R. Riachuelo, } 110 \\
\text { Centro, Curitiba }\end{array}$} & $\begin{array}{l}\text { Airbnb (empresa listada } \\
\text { na bolsa Nasdaq) }\end{array}$ \\
\hline & & & Shortstay (empresa local \\
\hline $\begin{array}{c}\text { Equity International } \\
\text { Fundo de investimentos, } \\
\text { Chicago }\end{array}$ & $\begin{array}{l}\text { THÁ Construtora, } \\
\text { Curitiba }\end{array}$ & & $\begin{array}{l}\text { Booking (empresa listada } \\
\text { na bolsa Nasdaq) }\end{array}$ \\
\hline
\end{tabular}

Fonte: websites do empreendimento e da incorporadora. Organização: os autores (2021).

Figura 5 - Fragmento de anúncios imobiliários de edifícios incorporados para locação em plataformas

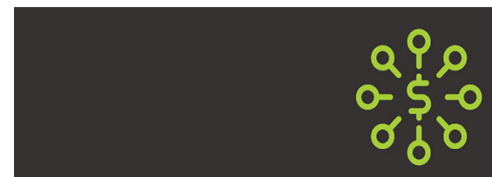

EMPREENDIMENTO COM

OCUPAÇÃO PREPARADA PARA A ECONOMIA COMPARTILHADA.

A convenção de condomínio do All foi adaptada para permitir locaçōes residenciais e locaçōes por temporada. Ou seja, você tem a flexibilidade

de explorar seu imóvel tanto com a locação tradicional, quanto com a locação por temporada pelos principais sites de hospedagem.

Fonte: à esquerda, fragmento de catálogo de lançamento do All you need. À direita, anúncio de Instagram da incorporadora Altma para o Vibe, ambos em Curitiba. 


\section{A financeiro-virtualização compartilhada da ocupação imobiliária}

Apesar de o Airbnb ter consolidado sua marca sob o discurso da "economia de compartiIhamento", este estudo demonstrou (Tabela 2) que a maioria dos imóveis anunciados na plataforma diz respeito, na verdade, a imóveis inteiros, não compartilhados, que estão mais próximos do setor hoteleiro do que da coabitação. Há, no entanto, uma proptech brasileira focada especificamente na intermediação da moradia compartilhada em apartamentos reformados no centro de São Paulo. A Yuca, plataforma restrita ao mercado paulistano, identifica-se como "uma startup brasileira de tecnologia imobiliária com investidores do mundo todo, que oferece uma solução inovadora de moradia compartilhada", operando o modelo de coliving, quando pessoas que não se conhecem dividem a moradia por intermédio de terceiros. Assim como as proptechs exploradas anteriormente, a Yuca também tem uma estrutura societária de escala global, conforme exposto no Quadro 4.

Por meio da Yuca, o proprietário-investidor pode aparecer na relação imobiliária de duas formas. A primeira é como proprietário direto de um imóvel que é colocado para aluguel na plataforma, com toda a gestão intermediada pela empresa (investimento tangível, chamado de buy to rent). A segunda forma assemelha-se à lógica dos fundos imobiliários (investimento intangível): por meio de financiamento coletivo (chamado de crowdfunding), é possível adquirir cotas de imóveis que possuem valor mínimo mais solvável para investidores em geral. Apesar de ter sido fundada com foco exclusivo no compartilhamento, a Yuca começou a experimentar o nicho da locação de estúdios para moradores individuais e considera expandi-lo (Arbex e Samor, 2020).

Quadro 4 - Financeirização em dois momentos de empreendimentos anunciados pela Yuca

\begin{tabular}{|c|c|c|l|}
\hline $\begin{array}{c}\text { Construção e incorporação } \\
\text { 10 momento da financeirização }\end{array}$ & Empreendimento & \multicolumn{2}{|c|}{$\begin{array}{c}\text { Ocupação } \\
\text { 20 momento da financeirização }\end{array}$} \\
\hline $\begin{array}{c}\text { Qualquer construtora } \\
\text { ou incorporadora }\end{array}$ & $\begin{array}{l}\text { Monashees (Brasil) } \\
\text { Terracotta Ventures (Brasil) } \\
\text { ONEVC (Brasil) } \\
\text { empreendimento }\end{array}$ & Yuca & $\begin{array}{l}\text { Creditas (Brasil) } \\
\text { Tishman Speyer (EUA) } \\
\text { Montage (EUA) } \\
\text { Investidores individuais }\end{array}$ \\
\hline
\end{tabular}

Fonte das informações: Exame (Dias, 2021) e websites dos investidores. Organização: os autores, em 2021. 
No modelo buy to rent, a empresa identifica imóveis potenciais em São Paulo, por meio de seu serviço de "curadoria de imóveis", e anuncia, em sua plataforma, o valor do investimento, incluindo a aquisição do imóvel, sua reforma, que é realizada pela própria Yuca, o custo do mobiliário, o Imposto de Transmissão de Bens Móveis (ITBI) e os custos cartoriais. $\mathrm{Na}$ curadoria são levados em consideração os fatores yield, resiliência e o potencial de valorização do produto imobiliário a partir da reforma. No único modelo crowdfunding anunciado atualmente (2020-2021), a cota mínima de participação é de 10 mil reais, e o retorno prometido é de $18,4 \%$ a.a. 0 financiamento coletivo, nesse caso, refere-se a três imóveis e, juridicamente, acontece por meio de uma Sociedade de Propósito Específico (SPE). A atuação da Yuca está restrita a regiões nobres da capital paulista: Bela Vista, Brooklin, Consolação, Itaim Bibi, Jardins, Moema, Oscar Freire, Pinheiros, Vila Madalena e Vila Olímpia, denotando que se trata de um modelo para consumidores com alto poder aquisitivo. Em novembro de 2020, a Yuca também criou um fundo de investimento de 40 milhões de reais, realizado com assessoria do Itaú BBA e captação junto de investidores profissionais e instituições (Capelas, 2020).

Um modelo de negócios semelhante é intermediado pela Roomgo, uma empresa inglesa que conecta proprietários com quartos extras para alugar e pessoas em busca de um espaço com aquele perfil. A proptech está ativa em, pelo menos, 20 países da Europa, Oceania, Ásia e Américas, inclusive no Brasil. 0 foco de atuação é a habitação compartilhada intermediada por canais digitais. Compartilhada tanto entre o proprietário do imóvel, que deseja rentabilizar um espaço extra subutilizado, quanto entre diferentes usuários interessados em um imóvel que esteja desocupado e possa ser alugado a mais de uma pessoa, no mesmo modelo da Yuca.

Em 2020, a concorrente SpareRoom, também britânica, adquiriu a Roomgo, que pertencia ao grupo Digital Ventures, tornando-se o maior serviço do mundo para encontrar roommates. As marcas SpareRoom e Roomgo permanecem sendo privadas e sem investidores externos (Property Notify, 2020). Manter um anúncio no topo da lista de ofertas tem um custo ao anunciante e é um dos mecanismos de geração de lucros para a proptech. 0 principal quesito de inovação está nos diversos mecanismos para encontrar o melhor par de locatário-e-locador. Conforme posto pelo jornal Folha de S.Paulo, a plataforma funciona como um Tinder do mercado imobiliário no qual, por exemplo, é possível identificar imóveis seguros para a coabitação de LGBTs, denotando que os mecanismos de aluguel digital evoluem juntamente com a digitalização e com a transformação da sociedade.

\section{Conclusões}

Os resultados da investigação delineiam um novo componente do regime urbano no Brasil: a disseminação de serviços digitais de facilitação de aluguel sem burocracia como intermediadores dos processos de geração de renda por meio da propriedade urbana. Na última década, a posse da propriedade alugada afasta-se, pois, do pequeno investidor em mercado imobiliário local e aproxima-se de grandes proprietários-investidores globais, que podem ser institucionais, individuais ou cotistas de fundos. Esses proprietários-investidores têm 
como objetivo obter rendimentos competitivos à renda fixa com a comercialização da moradia. Tal cenário apresenta um estágio avançado do processo de transição do setor imobiliário tradicional local para o complexo imobiliário-financeiro global, permeado pelas lógicas rentistas e pela virtualização das transações imobiliárias.

A análise dos modelos de negócios imobiliários apresentada neste artigo foi classificada em quatro ondas da ocupação imobiliária: (I) a financeirização, (II) a financeiro-desburocratização, (III) a financeiro-virtualização, e, por fim, (IV) a financeiro-virtualização compartilhada. Essas ondas demonstram a intensificação do processo de inovação que avança sobre o setor imobiliário, o que permite a geração do sobrelucro de inovação, pois novos modelos de negócios despertam curiosidade para serem experimentados, e, assim, a cada inovação, os limites do setor imobiliário são transcendidos e levados a um novo patamar.
O sobrelucro por inovação no mercado imobiliário, no entanto, pode sugerir um aumento no custo da moradia, o que abre novos espaços de pesquisa para compreender como os mecanismos do segundo momento da financeirização imobiliária aumentam o custo da moradia e pressionam o ônus com o aluguel, maior componente do déficit habitacional brasileiro desde 2011.

Os produtos mais recorrentes nessa nova lógica são os imóveis compactos, pois são mais solváveis para o investidor de bens tangíveis e garantem maior penetrabilidade no mercado da moradia descomplicada oferecida por meio de plataformas digitais. Nesse novo modelo de negócios centrados em produtos imobiliários com foco em investidores, a personalíssima relação do tipo imóvel/proprietário-locador/imobiliária/locatário-morador transforma-se no modelo ativo financeiro/ proprietário-investidor/plataforma digital/ assinante-morador-hóspede (Figura 6). Além

Figura 6 - Transição do setor imobiliário tradicional para o complexo imobiliário-financeiro

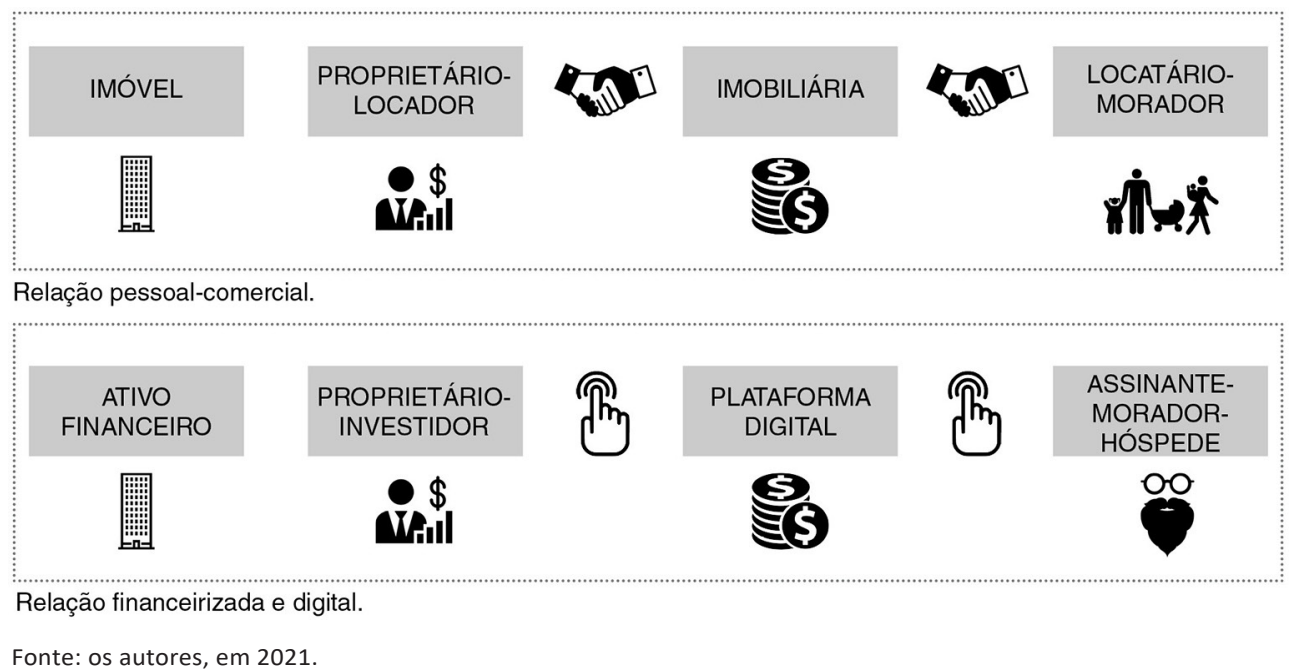


da financeirização da produção e incorporação do imóvel (primeiro momento da financeirização), as estruturas societárias das empresas que viabilizam o aluguel em ambientes virtuais são, na maioria das vezes, permeadas por capital de risco atuante em escala global ou são empresas de capital aberto com penetrabilidade em bolsas de diversos países (segundo momento da financeirização).

As conclusões da presente investigação estão em linha com discussões internacionais sobre a reestruturação neoliberal, as políticas governamentais e as inovações financeiras que criam condições para reinvestimentos lucrativos no mercado imobiliário, especialmente após a crise de 2008. Nesse período, intensificou-se, pois, o processo de transformação da moradia em ativo do capital globalizado. Apesar de avançarmos a compreensão dos novos modelos e estratégias de comercialização da moradia como serviço em território brasileiro, o fenômeno ainda precisa de continuados estudos, principalmente na escala de cada cidade. Entretanto, já é possível identificar impactos negativos no acesso justo à moradia na medida em que a busca pela rentabilização dupla do espaço construído, na construção e na ocupação, recria padrões de desigualdade social e espacial e, ao mesmo tempo, elide o potencial de a gestão urbana se voltar para construir uma cidade centrada em atender às necessidades locais culturalmente formadas em face do utilitarismo de mercado externamente imposto.

A análise ora apresentada avança na compreensão de novas estratégias do complexo imobiliário-financeiro para extração de renda do solo nos bairros mais bem providos de infraestrutura urbana, principalmente em metrópoles. Adicionalmente, aprofunda o entendimento sobre como essas estratégias podem tensionar o déficit imobiliário, ao tornar essas áreas centrais mais rentáveis quando a ocupação dos imóveis é intermediada por novas tecnologias e focada em contratos descomplicados, curtos e flexíveis. Esses modelos de negócios indicam uma barreira no acesso da classe trabalhadora à moradia nas áreas centrais por conta dos preços praticados, reproduzindo a lógica de periferização da moradia e a necessidade do deslocamento casa-trabalho entre a moradia periférica e os empregos centrais.

Por trás de todos os exemplos de estratégias, empresas e empreendimentos tratados no presente artigo, parece haver algum componente de inovação. Esse componente vai do aluguel sem burocracia à intermediação totalmente digital do contrato e à oferta de serviços sob demanda. Trata-se de um conjunto de facilidades que aproximam a comercialização da moradia a um serviço para quem habita e a um investimento para quem detém a propriedade. A inovação permite atingir um sobrelucro nesses negócios, pois os novos modelos permitem, além da renda da terra urbana e da forma arquitetônica, o lucro sobre a própria inovação que difere do mercado tradicional, pois são serviços inéditos com novas facilidades que se reinventam no contexto do capitalismo digital e criativo.

Em que medida, no entanto, o sobrelucro por inovação opõe-se à função social da propriedade é uma questão em aberto. Pode-se lançar a hipótese de que esses novos modelos de moradia comercializada para investidores pressionam as possibilidades de moradia acessível e bem localizada para as classes mais baixas. Essa discussão deixa outro questionamento para aprofundar em análises futuras: 
é possível imaginar um cenário no qual habitação seja investimento e, ao mesmo tempo, direito à cidade? Por ora, as análises denotam que as no-vas formas de exploração do espaço urbano pelo circuito imobiliário-financeiro renovam os desafios do direito à cidade na proporção em que a inovação aumenta o custo de acesso à moradia.

\section{[1] https://orcid.org/0000-0001-7615-0273}

Pontifícia Universidade Católica do Paraná, Escola de Belas Artes, Programa de Pós-Graduação em Gestão Urbana. Curitiba, PR/Brasil.

rafael@kalinoski.rocks

\section{[II] https://orcid.org/0000-0002-7346-1938}

Pontifícia Universidade Católica do Paraná, Escola de Belas Artes, Programa de Pós-Graduação em Gestão Urbana. Curitiba, PR/Brasil.

mario.p@pucpr.br

\section{Notas}

(1) Segundo documento Mapas das Construtechs e Proptechs, publicado pela Terracotta Ventures no primeiro semestre de 2021, há "[...] 839 startups ativas atuando ao longo de todo ciclo de projetos, construção, aquisição e propriedades em uso". Disponível em: https://www.terracotta. ventures/mapa-de-startups-2021.

(2) Segundo a B3, "Os Brazilian Depositary Receipts Patrocinados (BDR) são valores mobiliários emitidos no Brasil, que possuem como lastro ativos, geralmente ações, emitidos no Exterior". Disponível em: http://www.b3.com.br/pt_br/produtos-e-servicos/negociacao/renda-variavel/ brazilian-depositary-receipts-bdrs-patrocinados-niveis-i-ii-e-iii.htm.

(3) Disponível em: https://open.spotify.com/episode/5XsOU7g6pQSatOdWIObGiq?si=hnIHfYDHRwCJ jP8S1yf7xQ.

(4) Todas as informações públicas do fundo podem ser obtidas em https://fii.housi.com.br/.

(5) No mercado financeiro, tanto para avaliar ações quanto Flls, o indicador P/VP abaixo de 1 indica que o papel está barato, enquanto o P/VP acima de 1 indica que o papel está caro, já que é negociado por um preço maior que o valor patrimonial da cota. No entanto, este é apenas um dentre diversos indicadores gráficos e fundamentalistas que são levados em consideração por investidores. 
(6) Este indicador do mercado financeiro indica a relação entre os dividendos distribuídos e o preço dos papéis. Quanto maior o DY, mais atrativo é o papel para o investidor que está em busca de renda que, no caso de Flls, é paga mensalmente. O diferencial aqui é que, ao invés de comprar um imóvel inteiro (investimento imobiliário tangível) e administrar seu aluguel, o investidor pode fazer aportes menores por meio de cotas (investimento intangível). O trabalho de Mieli (2008) esclarece em profundidade como funcionam os Flls e como emergiram no mercado brasileiro em substituição parcial ao investimento imobiliário tangível.

(7) Jargão do mercado em referência a empresas avaliadas em um bilhão de dólares antes de abrir capital em bolsa. Enquadram-se nesse critério as startups brasileiras Loggi, 99, iFood, Movile, Nu-bank, Gympass e Quinto Andar.

\section{Referências}

AALBERS, M. B.; HAILA, A. (2018). A conversation about land rent, financialization and housing. Urban Studies, v. 55, n. 8, pp. 1821-1835. DOI: 10.1177/0042098018759251.

ABRAMO, P. (1995). A regulação urbana e o regime urbano: a estrutura urbana, sua reprodutibilidade e o capital. Ensaios FEE, v. 16, n. 2, pp. 510-555.

ARANTES, O.; VAINER, C.; MARICATO, E. (2002). A cidade do pensamento único: desmanchando consensos. Petrópolis, Vozes.

ARBEX, P.; SAMOR, G. (2020). Morar nas megalópoles virou um inferno. A Yuca diz ter a solução. Brazil Journal, 29 jan. Disponível em: https://braziljournal.com/morar-nas-megalopoles-virouum-inferno-a-yuca-diz-ter-a-solucao. Acesso em: 3 jul 2021.

AUGUST, M. (2020). The financialization of Canadian multi-family rental housing: From trail-er to tower. Journal of Urban Affairs, v. 42, n. 7, pp. 975-977. DOI: 10.1080/07352166.2019.1705846.

CAPELAS, B. (2020). Startup de aluguel de casa compartilhada, Yuca lança fundo imobiliário de R\$ 40 mi. Terra, 26 nov. Disponível em: https://www.terra.com.br/noticias/tecnologia/inovacao/ startup-de-aluguel-de-casa-compartilhada-yuca-lanca-fundo-imobiliario-de-r-40-mi,bd9275013 35bdc596e338343c265e660h1glptsa.html. Acesso em: 11 mar 2021.

CAVALCANTE, A. et al. (2018). Financialization and Space: Theoretical and empirical contributions. Revista Brasileira de Estudos Urbanos e Regionais, v. 20, n. 2, pp. 193-220. DOI: 10.22296/2317-1529.2018v2 On2p193.

CHARLES, S. L. (2020). The financialization of single-family rental housing: An examination of real estate investment trusts' ownership of single family houses in the Atlanta metropolitan area. Journal of Urban Affairs, v. 43, n. 8, pp. 1321-1341. DOI: 10.1080/07352166.2019.1662728

D'ÁVILA, M. Z. (2020). Fundos imobiliários residenciais ganham espaço na Bolsa, com foco em aluguéis, incorporação e compra e venda. InfoMoney, 30 jul. Disponível em: https://www.infomoney. com.br/onde-investir/fundos-imobiliarios-residenciais-ganham-espaco-na-bolsa-com-foco-emalugueis-incorporacao-e-compra-e-venda/. Acesso em: 11 mar 2020. 
DIAS, M. C. (2021). Startup que quer mudar a moradia urbana, Yuca capta R\$ 56 milhões. Exame, 22 jun. Disponível em: https://exame.com/pme/startup-yuca-capta-56-milhoes/. Acesso em: 22 jun 2021.

EPSTEIN, G. A. (2005). Financialization and the world economy. Cheltenham e Northampton, Edward Elgar Publisher.

FERNANDEZ, R.; AALBERS, M. B. (2016). Financialization and housing: between globalization and varieties of capitalism. Competition and Change, v. 20, n. 2, pp. 71-88. DOI: 10.1177/1024529415623916.

FIX, M. (2009). Uma ponte para a especulação - ou a arte da renda na montagem de uma "cidade global". Caderno CRH, v. 22, n. 55, pp. 41-64.

(2011). Financeirização e transformações recentes no circuito imobiliário no Brasil. Tese de doutorado. Campinas, Universidade Estadual de Campinas.

FIX, M.; PAULANI, L. M. (2019). Considerações teóricas sobre a terra como puro ativo financeiro e o processo de financeirização. Brazilian Journal of Political Economy, v. 39, n. 4, pp. 638-657. DOI: 10.1590/0101-31572019-2954.

GRIFFITH, E. (2020). Airbnb prices I.P.O. at $\$ 68$ a share, for a $\$ 47$ billion valuation. The New York Times, 9 dez. Disponível em: https://www.nytimes.com/2020/12/09/business/airbnb-ipo-price.html. Acesso em: 11 mar 2021.

GUIRONNET, A.; ATTUYER, K.; HALBERT, L. (2015). Building cities on financial assets: the financialisation of property markets and its implications for city governments in the Paris city-region. Urban Studies, v. 53, n. 7, pp. 1142-1464. DOI: 10.1177/0042098015576474.

HALBERT, L.; ATTUYER, K. (2016). Introduction: The financialisation of urban production: Conditions, mediations and transformations. Urban Studies, v. 53, n. 7, pp. 1347-1361. DOI: 10.1177/0042098016635420.

HARVEY, D. (2005). A produção capitalista do espaço. São Paulo, Annablume.

(2008). O neoliberalismo: história e implicações. São Paulo, Loyola.

(2012). O Direito à cidade. Lutas Sociais, v. 29, pp. 73-89.

IBGE - Instituto Brasileiro de Geografia e Estatística (2020). Regiões de influência das cidades 2018. Rio de Janeiro, IBGE.

IOANNOU, S.; WÓJCIK, D. (2021). Finance and growth nexus: an international analysis across cities. Urban Studies, v. 58, n. 1, pp. 223-242. DOI: 10.1177/0042098019889244.

KLINK, J.; SOUZA, M. B. de (2017). Financeirização: conceitos, experiências e a relevância para o campo do planejamento urbano brasileiro. Cadernos Metrópole, v. 19, n. 39, pp. 379-406. DOI: 10.1590/2236-9996.2017-3902.

KRIPPNER, G. R. (2005). The financialization of the American economy. Socio-Economic Review, v. 3, pp. 173-208. DOI: 10.1093/SER/mwi008.

LACERDA, N.; BERNARDINO, I. L. (2020). Ressemantização das áreas centrais das cidades brasileiras e mercado imobiliário habitacional: o caso recifense (Brasil). Cadernos Metrópole. São Paulo, v. 22, n. 49, pp. 913-934. DOI: 10.1590/2236-9996.2020-4911. 
LÓPEZ, L. M. (2020). El capital inmobiliário-financeiro y la producción de la ciudad latinoa-mericana hoy. Cadernos Metrópole. São Paulo, v. 22, n. 49, pp. 665-682. DOI: 10.1590/2236-9996.20204901.

MARTINS, F. M. (2020). Agentes, produtos e implicações da produção imobiliária de habitação multifamiliar em Curitiba, 2010-2018. Dissertação de mestrado. Curitiba, Universidade Federal do Paraná.

MATTOS, C. (2007). Globalizacion, negocios inmobiliarios y transformación urbana. Nueva Sociedad, n. 212, pp. 82-96.

MELO, E. O. de. (2021). Financeirização, governança urbana e poder empresarial nas cidades brasileiras. Cadernos Metrópole. São Paulo, v. 23, n. 50, pp. 41-66. DOI: 10.1590/2236-9996.2021-5002.

MIELE, S. A. de F. (2008). O movimento da economia financeira: a dinâmica imobiliária de São Paulo. Dissertação de mestrado. São Paulo, Universidade de São Paulo.

PANIZZI, W. (2020). Rent-seeking urbano, planejamento urbano e valor imobiliário: quem manda e desmanda na cidade ? e-metropolis, ano 11, n. 40, pp. 18-24.

PROPERTY NOTIFY (2020). SpareRoom Acquires Rival Roomgo - Creating World's Largest Roomate Finding Service. Property Notify, 7 set. Disponível em: https://www.propertynotify.co.uk/news/ press-releases/spareroom-acquires-rival-roomgo-creating-worlds-largest-roommate-findingservice/. Acesso em: 13 mar 2021.

RUFINO, M. B. C. (2012). Incorporação da metrópole: centralização do capital no imobiliário e nova produção de espaço em Fortaleza. Tese de doutorado. São Paulo, Universidade de São Paulo.

SAMBRANA, C. (2021). A virada de chave da Housi agora passa pelas "franquias". Neofeed, 4 jan. Disponível em: https://neofeed.com.br/blog/home/a-virada-de-chave-da-housi-agora-passapelas-franquias/. Acesso em: 11 mar 2020.

SANFELICI, D. (2013). Financeirização e a produção do espaço urbano no Brasil: uma contribuição ao debate. Eure, v. 39, n. 118, pp. 27-46.

SANFELICI, D.; HALBERT, L. (2016). Financial markets, developers and the geographies of housing in Brazil: A supply-side account. Urban Studies, v. 53, n. 7, pp. 1465-1485. DOI: 10.1177/0042098015590981.

(2019). Financial market actors as urban policy-makers: the case of real estate investment trusts in Brazil. Urban Geography, v. 40, n. 1, pp. 83-103. DOI: 10.1080/02723638.2018.1500246.

SANTORO, P. F.; ROLNIK, R. (2017). Novas frentes de expansão do complexo imobiliário-financeiro em São Paulo. Cadernos Metrópole. São Paulo, v. 19, n. 39, pp. 407-431. DOI: 10.1590/22369996.2017-3903.

SILVA, M-V.G.; PROCOPIUCK, M. (2019). A produção científica sobre gestão urbana: análise bibliométrica de 2010 a 2017. Eure, v. 45, n. 136, pp. 281-95.

SOARES, P. R. R. (2020). Metrópoles e cidades na atualidade. e-metropolis, ano 11, n. 40, pp. $34-42$.

SORKIN, A. R. et al. (2020). Airbnb's Stunning I.P.O. The New York Times, 11 dez. Disponível em: https:// www.nytimes.com/2020/12/11/business/dealbook/airbnb-ipo-chesky.html. Acesso em: 11 mar 2021. 
THEODORE, N.; PECK, J.; BRENNER, N. (2009). Urbanismo neoliberal: la ciudad y el imperio de los mercados. Temas Sociales, n. 66, pp. 1-11.

VALFRÉ, L. G.; RIBEIRO, M. G. (2020). Um jeito de morar ou de investir ? e-metropolis, ano 11, n. 42, pp. 31-40.

VEJA (2019). Startup de aluguel de imóveis Quinto Andar é o nono unicórnio brasileiro. VEJA, 10 set. Disponível em: https://veja.abril.com.br/economia/startup-de-aluguel-de-imoveis-quintoandar-e-o-nono-unicornio-brasileiro/. Acesso em: 11 mar 2021.

WEIGERT, I. (2020). Entre a preservação e o desenvolvimento: a rua Riachuelo na área central de Curitiba. Dissertação de mestrado. Curitiba, Universidade Federal do Paraná.

Texto recebido em 31/mar/2021

Texto aprovado em 18/jun/2021 